\title{
Association Between Alcohol use in Pregnancy and Preeclampsia or Hypertension in Pregnancy: A Systematic Review
}

\section{Weiyan Gong}

Department of Obstetrics,Shandong Provincial Hospital Affiliated to Shandong First Medical University,Jinan,Shandong,China;OMNI Research Group,Ottawa Hospita Research Institute.

\section{$\mathrm{Na}$ Zeng}

OMNI Research Group,Ottawa Hospital Research Institute;School of Epidemiology and Public Health,University of Ottawa Faculty of Medicine

\section{Daniel Corsi}

OMNI Research Group,Ottawa Hospital Research Institute;Better Outcomes and Registry Network(BORN) Ontario;School of Epidemiology and Public Health,University of Ottawa Faculty of Medicine)

\section{Shi Wu Wen ( $\nabla$ swwen@ohri.ca)}

Ottawa Hospital Research Institute https://orcid.org/0000-0002-7227-0283

\section{Research article}

Keywords: alcohol, preeclampsia, hypertensive disorders of pregnancy

Posted Date: June 25th, 2020

DOI: https://doi.org/10.21203/rs.3.rs-36772/v1

License: (c) (i) This work is licensed under a Creative Commons Attribution 4.0 International License. Read Full License 


\section{Abstract}

\section{Background}

To summarize evidence on the association of maternal alcohol consumption during pregnancy with preeclampsia (PE) or hypertensive disorders of pregnancy (HDP).

\section{Methods}

We searched PubMed, EMBASE, PsycINFO, and Cochrane Central Register of Controlled Trials databases. We included original studies that presented relative risks, odds ratios, or data to calculate the risks for the association of alcohol consumption during pregnancy with PE or HDP. We used the Newcastle-Ottawa Scale to assess study quality. We conducted a random-effects meta-analysis to calculate the pooled association of gestational alcohol use with PE or HDP.

\section{Results}

Thirty-seven articles met the criteria for inclusion. The total study population was 4,434,003 women with 170,481 cases of PE and 467,055 women with 41,708 cases of HDP. For all included studies, there was no significant association between alcohol consumption during pregnancy and incidence of $P E(O R=0.93$, $95 \% \mathrm{Cl}$ : 0.73-1.20), with statistical significant heterogeneity $\left(\mathrm{I}^{2}=91 \%, \mathrm{P}<0.00001\right)$. Among the subgroup of prospective cohort studies, the pooled results showed that alcohol consumption during pregnancy had a protective effect on $\mathrm{PE}(\mathrm{OR}=0.64,95 \% \mathrm{Cl}: 0.54-0.76)$, and with no statistical heterogeneity $\left(\mathrm{I}^{2}=0 \%\right.$, $P=0.56)$. The results from the subgroup of retrospective cohort and case-control studies showed that alcohol consumption during pregnancy was not associated with $\mathrm{PE}$, with odds ratios of 1.07 (0.65-1.74) and 1.02 (0.64-1.61), respectively, and with statistically significant heterogeneity. The pooled OR for the association between alcohol consumption during pregnancy and HDP was 0.98 (95\% Cl: 0.75-1.29), with considerable heterogeneity $\left(\mathrm{I}^{2}=90 \% \mathrm{P}<0.00001\right)$.

\section{Conclusion}

Overall, there is no apparent association of alcohol consumption during pregnancy with PE or HDP. In prospective cohort studies, an evident protective effect is likely due to residual confounding. Further studies should consider alternative designs such as mendelian randomization, which can overcome some of the limitations of conventional prospective studies.

\section{Background}

Preeclampsia (PE), a subclass of hypertensive disorders of pregnancy (HDP), is most commonly defined by new-onset hypertension after 20 weeks of gestation with new-onset proteinuria or end-organ damage [1]. PE and other hypertension disorders account for $14 \%$ of maternal deaths worldwide [2]. PE is also the main reason for preterm birth and perinatal mortality. Stillbirth risk pregnancies affected by PE at 34 
weeks was seven-fold higher than pregnancies without PE [3]. In the United States, the cost burden of PE within the first year of delivery was $\$ 2.18$ billion [4]. However, the etiology of PE is still elusive.

Some maternal factors, such as obesity, diabetes mellitus, and renal disease, which also correlated with the risk of cardiovascular disease in women, were associated with PE [5]. Alcohol consumption was associated with an increased risk of developing cardiovascular disease, even at lower levels of use [6]. Further, some intervention studies [7] and Mendelian randomization studies [8] confirmed a robust causal relationship between alcohol intake and hypertension in the non-pregnant population. Moderate-to-heavy drinkers have a higher risk of hypertension [9]. However, there is no consistent conclusion on the relationship between alcohol exposure during pregnancy with PE or HDP.

Because alcohol exposure during pregnancy can cause congenital and neurodevelopmental abnormalities (such as fetal alcohol spectrum disorders), most clinical guidelines recommend abstinence during pregnancy $[10,11]$. Still, up to 10 percent of pregnant women drink alcohol in Canada and 15 percent in the United States [12]. In addition to the effects of alcohol on the fetus, there is concern about the effects of alcohol during pregnancy on the mother on developing conditions such as PE and HDP. Therefore, we conducted a systematic review of the literature to summarize available evidence on association of maternal alcohol consumption during pregnancy with PE and HDP.

\section{Methods}

A protocol of this systematic review is available from the PROSPERO systematic review register (registration number: CRD42020167063).

\section{Search Strategy And Study Selection}

We collaborated with an information specialist to design the search strategy. On January 27, 2020, we searched four databases: Embase (1947 to January 27, 2020), MEDLINE (1946 to January 27, 2020), Cochrane Central Register of Controlled Trials (up to December 2019), and PsycINFO using the follow terms: Preeclampsia, gestational hypertension, and alcohol /ethanol (full search strategy described in Table S1).

No restrictions were applied to the study design (or types of study) and publishing language during the searching step, however we excluded case series and case reports. Conference articles and abstracts were also included if they investigated the association of maternalalcohol consumption during pregnancy with PE or HDP and were not published at a later stage. We also conducted a hand searching for citations and cited references in identified articles, as well as reference lists of reviews.

Original studies which sampled from the general pregnant women population and presented relative risk or odds ratios (or data to calculate these risks) of PE or HDP associated with alcohol consumption during pregnancy were included in this review. 
Exposure was any alcohol use during pregnancy. The outcome was PE or HDP.

Exclusion criteria included studying alcohol consumption only before pregnancy, not during pregnancy, and non-clinical diagnosis for PE or HDP .

After imported the references on Covidence which is an online literature screening and data extraction software. W.Y.G and N.Z screened the title and abstracts based on the inclusion criteria separately. If discrepancies arise, we resolve them through conference and review full-text. The unsolved discrepancies were adjudicated by D.J.C.

\section{Data Extraction}

W.Y.G and N.Z extracted the data. The following data were extracted: title, last name of the first author, publication date, study design, country/region of study, the period of the study, whether adjusting for confounders, the number of alcohol consumption and non-alcohol consumption during pregnancy, the number of $\mathrm{PE}$ in alcohol group and non-alcohol group, how the alcohol consumption was ascertained, the definition of PE or HDP.

\section{Quality Assessment}

All included studies were assessed for methodological quality. Non-randomized case-control studies and cohort studies used Newcastle-Ottawa Scale (NOS)[13] which include three domains and eight items of study design and quality of reporting: Selection (4 items), Comparability (1 item), and ascertainment of exposure ( 3 items). More stars indicate less risk of bias. Agency for Healthcare Research and Quality (AHRQ) methodological checklist was used to assess cross-sectional studies.

We described the risk of bias in the results, and used the total score to assess the quality of the literature, with higher scores indicating better study quality.

\section{Meta-analysis}

When analyzing the association of alcohol consumption with PE or HDP, we converted whether have alcohol consumption during pregnancy into a dichotomous variable (yes or no), the outcome of whether PE or HDP, and imported the numbers of exposure and outcome extracted from each study into Revman5 software. Considering the influence of study design on the results, the included studies were divided into prospective cohort, retrospective cohort, and case-control studies. Generic inverse variance methods analyzed the association of alcohol and HDP because some studies just reported the odds ratio. The heterogeneity across studies is assessed by $\mathrm{I}^{2}, \mathrm{I}^{2}>50 \%$ means high heterogeneity. 
We used Revman5 software to make forest plots and funnel plots. Funnel plot asymmetry inspected visually was used to assess the potential for publication bias[14].

Sensitivity analysis was conducted to explore the potential sources of heterogeneity [15]. First, we sequentially excluded one study and recalculated the $\mathrm{l}^{2}$, the study which was omitted from the metaanalysis to drop $\mathrm{I}^{2}$ below $25 \%$ was the plausible explanation for the heterogeneity. Second, we removed the low quality studies scoring 'less than 4 ' on the NOS. Third, we excluded studies that had a small sample size (less than 10 participants). Subgroup analysis was also conducted for studies with different designs.

\section{Results}

\section{Characteristics Of The Included Studies}

A total of 888 non-duplicate works were identified through the literature search, including 12 manually retrieved from systematic reviews and reference lists of identified studies. After title/abstract screening and full-text screening, 37 articles were included for the current systematic review (Fig. 1).

Eleven out of the 37 studies (30\%) were conducted in the USA, followed by Ethiopia (11\%) and the Netherlands (11\%). These included studies were conducted between 1984 and 2019. The sample sizes of these studies varied from 105 [16] to 2,963,888 [17]. The prevalence of alcohol consumption during pregnancy among different samples varied between $0.2 \%$ (China) [18] to 73.9\% (SCOPE study) [19].

The main outcome of 29 out of the 37 articles was PE. In these 29 studies, 7 were prospective cohort studies, 7 were retrospective cohort studies, and 15 were case-control studies. Eight of the 37 articles were used to analyze the association between alcohol consumption during pregnancy and HDP.

We evaluated the 35 cohort and case-control studies by the NOS (Table 1). Two cross-sectional studies were assessed by an 11-item checklist recommended by Agency for Healthcare Research and Quality (AHRQ). Of these, 5 case-control studies, 6 prospective cohort studies, and 1 cross-sectional study were considered high quality. The main aspect responsible for the lower quality of these cohort studies is comparability as the most of these studies only provide crude odds ratios (OR), without adjustment for confounding factors. The reasons for low quality of case-control studies include the control group were selected from hospitalized population (not community controls), and ascertainment of exposure was not blinded or only based on medical record and self-report. 
Table 1

Characteristics of Studies in Systematic Review

$\begin{array}{lllll}\text { Author study design } & \text { exposure ascertainment } & \text { country } & \begin{array}{l}\text { study } \\ \text { year }\end{array} & \begin{array}{l}\text { Quality } \\ \text { assessment }\end{array}\end{array}$

\section{PE as outcome}

\begin{tabular}{|c|c|c|c|c|}
\hline $\begin{array}{l}\text { Bandoli } \\
\text { 2018[17] }\end{array}$ & $\begin{array}{l}\text { retrospective } \\
\text { population- } \\
\text { based cohort }\end{array}$ & $\begin{array}{l}\text { birth certificate and } \\
\text { hospital discharge } \\
\text { record }\end{array}$ & USA & $\begin{array}{l}2007- \\
2012\end{array}$ \\
\hline $\begin{array}{l}\text { Bobic } \\
2015[16]\end{array}$ & case-control & - & Croatia & 2015 \\
\hline $\begin{array}{l}\text { Bommarito } \\
2019[34]\end{array}$ & prospective & $\begin{array}{l}\text { At the first visit (median, } \\
10 \text { weeks gestation), } \\
\text { women completed } \\
\text { detailed questionnaires } \\
\text { of demographic } \\
\text { information }\end{array}$ & USA & $\begin{array}{l}2006- \\
2008\end{array}$ \\
\hline
\end{tabular}

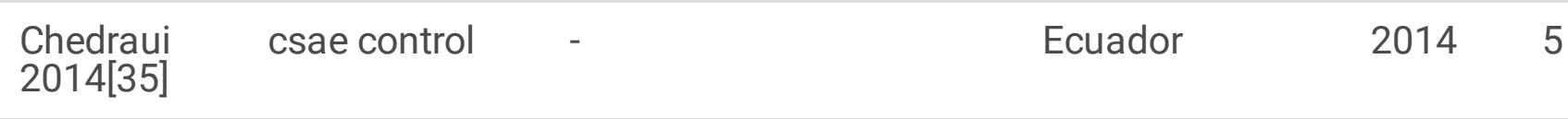

\begin{tabular}{|c|c|c|c|c|}
\hline $\begin{array}{l}\text { Coolman } \\
\text { 2012[36] }\end{array}$ & $\begin{array}{l}\text { population- } \\
\text { based } \\
\text { prospective } \\
\text { cohort study }\end{array}$ & $\begin{array}{l}\text { alcohol consumption } \\
\text { was assessed by } \\
\text { questionnaires in each } \\
\text { trimester. }\end{array}$ & Netherlands & $\begin{array}{l}2002- \\
2006\end{array}$ \\
\hline
\end{tabular}

$\begin{array}{llllll}\begin{array}{l}\text { Cota } \\ \text { 2006[37] }\end{array} & \text { case-contro } & \begin{array}{l}\text { medical records } \\ \text { postpartum }\end{array} & \text { Brazil } & 2004 & 4\end{array}$

\begin{tabular}{|c|c|c|c|c|}
\hline $\begin{array}{l}\text { Endeshaw } \\
2014[38]\end{array}$ & Case-Control & interview after delivery & Ethiopia & 2014 \\
\hline $\begin{array}{l}\text { Eskenazi } \\
\text { 1991[39] }\end{array}$ & case-control & $\begin{array}{l}\text { abstracted from } \\
\text { medical charts }\end{array}$ & $\begin{array}{l}\text { Northern } \\
\text { California(USA) }\end{array}$ & $\begin{array}{l}1984- \\
1985\end{array}$ \\
\hline $\begin{array}{l}\text { Fang } \\
\text { 2009[40] }\end{array}$ & case-control & $\begin{array}{l}\text { a } 45-\text { minute in-person } \\
\text { interview in which } \\
\text { trained research } \\
\text { personnel used a } \\
\text { structured questionnaire }\end{array}$ & Thailand & $\begin{array}{l}2006- \\
2007\end{array}$ \\
\hline
\end{tabular}

$\begin{array}{llllll}\begin{array}{l}\text { Grum } 2017[41] \\ \text { Jhee }\end{array} & \begin{array}{l}\text { unmatched } \\ \text { case control } \\ \text { study }\end{array} & \begin{array}{l}\text { using pretested } \\ \text { interviewer administered } \\ \text { questionnaire }\end{array} & \text { Ethiopia } & 2015- & 7 \\ \begin{array}{l}\text { retrospective } \\ \text { 2019[42] }\end{array} & \begin{array}{l}\text { retrieved from electronic } \\ \text { medical records }\end{array} & \text { Korea } & 2016 & 2005- & 6 \\ \begin{array}{l}\text { Kharkova } \\ \text { 2017[43] }\end{array} & \begin{array}{l}\text { retrospective } \\ \text { study }\end{array} & \begin{array}{l}\text { alcohol abuse as } \\ \text { diagnosed by a doctor } \\ \text { based on medical } \\ \text { record }\end{array} & \text { Russia } & 2006- & 6 \\ & & & 2011 & \\ & & & & & \end{array}$

Figure 1: Flow-chart of study selection. 


\begin{tabular}{|c|c|c|c|c|c|}
\hline Author & study design & exposure ascertainment & country & $\begin{array}{l}\text { study } \\
\text { year }\end{array}$ & $\begin{array}{l}\text { Quality } \\
\text { assessment }\end{array}$ \\
\hline $\begin{array}{l}\text { Kiondo } \\
2012[44]\end{array}$ & case control & $\begin{array}{l}\text { the women were } \\
\text { interviewed about their } \\
\text { socio-demographic } \\
\text { characteristics }\end{array}$ & Uganda & $\begin{array}{l}2008- \\
2009\end{array}$ & 7 \\
\hline $\begin{array}{l}\text { KLONOFF- } \\
\text { COHEN } \\
1996[45]\end{array}$ & case-control & $\begin{array}{l}\text { obtained from a } \\
\text { standardized telephone } \\
\text { interview }\end{array}$ & USA & $\begin{array}{l}1984- \\
1987\end{array}$ & 7 \\
\hline $\begin{array}{l}\text { KURKI } \\
2000[46]\end{array}$ & $\begin{array}{l}\text { prospective } \\
\text { population- } \\
\text { based study }\end{array}$ & $\begin{array}{l}\text { by a structured } \\
\text { questionnaire at at their } \\
\text { first prenatal visit } \\
\text { between } 8-17 \text { weeks' } \\
\text { gestation }\end{array}$ & Finland & 2000 & 7 \\
\hline $\begin{array}{l}\text { Lafaurie } \\
2020[47]\end{array}$ & case control & $\begin{array}{l}\text { obtained from hospital } \\
\text { information systems } \\
\text { and medical records }\end{array}$ & Colombia & 2019 & 4 \\
\hline $\begin{array}{l}\text { Laine } \\
2015[48]\end{array}$ & $\begin{array}{l}\text { nested case- } \\
\text { control }\end{array}$ & $\begin{array}{l}\text { based on self report at } \\
\text { either baseline or } \\
\text { postpartum } \\
\text { examination interview. }\end{array}$ & USA & $\begin{array}{l}2004- \\
2007\end{array}$ & 4 \\
\hline $\begin{array}{l}\text { Lardoeyt } \\
2013 \text { [22] }\end{array}$ & $\begin{array}{l}\text { case-control } \\
\text { study }\end{array}$ & $\begin{array}{l}\text { in-depth interviews were } \\
\text { conducted using an } \\
\text { instrument designed for } \\
\text { the study }\end{array}$ & Cuba & $\begin{array}{l}2007- \\
2009\end{array}$ & 5 \\
\hline $\begin{array}{l}\text { Leemaqz } \\
2016[19]\end{array}$ & $\begin{array}{l}\text { prospective } \\
\text { cohort }\end{array}$ & $\begin{array}{l}\text { dietary and lifestyle } \\
\text { questionnaires were } \\
\text { recorded at } 15 \text { weeks' } \\
\text { and } 20 \text { weeks' gestation }\end{array}$ & $\begin{array}{l}\text { Australia, New } \\
\text { Zealand,Ireland, } \\
\text { United } \\
\text { Kingdom }\end{array}$ & $\begin{array}{l}2004- \\
2011\end{array}$ & 8 \\
\hline $\begin{array}{l}\text { Meertens } \\
\text { 2019[49] }\end{array}$ & $\begin{array}{l}\text { prospective } \\
\text { cohort study }\end{array}$ & $\begin{array}{l}\text { by a web-based } \\
\text { questionnaire before } 16 \\
\text { weeks of gestation } \\
\text { (pregnancy } \\
\text { questionnaire) }\end{array}$ & Netherlands & $\begin{array}{l}2013- \\
2015\end{array}$ & 7 \\
\hline $\begin{array}{l}\text { Mekie } \\
2020[50]\end{array}$ & $\begin{array}{l}\text { Age matched } \\
\text { case-control } \\
\text { study }\end{array}$ & $\begin{array}{l}\text { collected through an } \\
\text { interview using a } \\
\text { questionnaire }\end{array}$ & Ethiopia & 2018 & 7 \\
\hline $\begin{array}{l}\text { Nobles } \\
2019[51]\end{array}$ & $\begin{array}{l}\text { retrospective } \\
\text { cohort }\end{array}$ & $\begin{array}{l}\text { abstracted from delivery } \\
\text { electronic medical } \\
\text { records(yes/no) }\end{array}$ & USA & $\begin{array}{l}2002- \\
2010\end{array}$ & 6 \\
\hline $\begin{array}{l}\text { RUDRA } \\
\text { 2005[52] }\end{array}$ & $\begin{array}{l}\text { case-control } \\
\text { study }\end{array}$ & $\begin{array}{l}\text { an in-person structured } \\
\text { interview questionnaire } \\
\text { to collect information }\end{array}$ & USA & $\begin{array}{l}1998- \\
2002\end{array}$ & 5 \\
\hline
\end{tabular}

Figure 1: Flow-chart of study selection. 


\begin{tabular}{|c|c|c|c|c|c|}
\hline Author & study design & exposure ascertainment & country & $\begin{array}{l}\text { study } \\
\text { year }\end{array}$ & $\begin{array}{l}\text { Quality } \\
\text { assessment }\end{array}$ \\
\hline $\begin{array}{l}\text { Salihu } \\
2011[20]\end{array}$ & $\begin{array}{l}\text { retrospective } \\
\text { cohort }\end{array}$ & $\begin{array}{l}\text { Missouri vital record } \\
\text { system }\end{array}$ & USA & $\begin{array}{l}1989- \\
2005\end{array}$ & 6 \\
\hline $\begin{array}{l}\text { Sandström } \\
2019[53]\end{array}$ & $\begin{array}{l}\text { prospectively } \\
\text { population- } \\
\text { based cohort } \\
\text { study }\end{array}$ & $\begin{array}{l}\text { Alcohol consumption at } \\
\text { registration are self- } \\
\text { reported }\end{array}$ & Sweden & $\begin{array}{l}2008- \\
2013\end{array}$ & 6 \\
\hline $\begin{array}{l}\text { Thompson } \\
2014[54]\end{array}$ & $\begin{array}{l}\text { prospective } \\
\text { cohort study }\end{array}$ & $\begin{array}{l}\text { interview in which } \\
\text { trained research } \\
\text { personnel used a } \\
\text { structured questionnaire } \\
\text { before } 20 \text { weeks' } \\
\text { gestation }\end{array}$ & $\begin{array}{l}\text { USA(Swedish } \\
\text { Medical Center) }\end{array}$ & $\begin{array}{l}1996- \\
2008\end{array}$ & 7 \\
\hline $\begin{array}{l}\text { Wang } \\
2015[18]\end{array}$ & $\begin{array}{l}\text { birth cohort } \\
\text { study }\end{array}$ & $\begin{array}{l}\text { in-person interviews at } \\
\text { the hospital using a } \\
\text { standardized and } \\
\text { structured questionnaire } \\
\text { after dilivery }\end{array}$ & China & $\begin{array}{l}2010- \\
2012\end{array}$ & 6 \\
\hline $\begin{array}{l}\text { Xiong } \\
2000[55]\end{array}$ & $\begin{array}{l}\text { retrospective } \\
\text { cohort }\end{array}$ & $\begin{array}{l}\text { data were derived from } \\
\text { delivery record }\end{array}$ & Canada & $\begin{array}{l}1995- \\
1997\end{array}$ & 6 \\
\hline $\begin{array}{l}\text { Xiong } \\
2009[56]\end{array}$ & case-control & $\begin{array}{l}\text { obtained during } \\
\text { personal interviews }\end{array}$ & canada & $\begin{array}{l}2003- \\
2006\end{array}$ & 4 \\
\hline \multicolumn{6}{|c|}{ HDP as outcome } \\
\hline $\begin{array}{l}\text { Baugh } \\
2016[57]\end{array}$ & $\begin{array}{l}\text { national } \\
\text { population- } \\
\text { based survey } \\
\text { (retrospective) }\end{array}$ & $\begin{array}{l}\text { contacted by mail and/ } \\
\text { or telephone to } \\
\text { participate } 2-4 \text { months } \\
\text { after giving birth }\end{array}$ & USA & $\begin{array}{l}2000- \\
2010\end{array}$ & 6 \\
\hline $\begin{array}{l}\text { Chada } \\
2007[58]\end{array}$ & case-control & $\begin{array}{l}\text { Two midwives } \\
\text { administered } \\
\text { questionnaires on the } \\
\text { day of delivery }\end{array}$ & Argentina & 2007 & 4 \\
\hline $\begin{array}{l}\text { Iwama } \\
2019[59]\end{array}$ & $\begin{array}{l}\text { prospective } \\
\text { birth cohort } \\
\text { study }\end{array}$ & $\begin{array}{l}\text { obtained from the two } \\
\text { questionnaires, namely, } \\
\text { T1( } 16.5 \text { weeks) and } \\
\text { T2囚27.9 weeks } \square\end{array}$ & Japan & $\begin{array}{l}2011- \\
2014\end{array}$ & 9 \\
\hline $\begin{array}{l}\text { Masho } \\
2015[60]\end{array}$ & $\begin{array}{l}\text { prospective } \\
\text { cohort }\end{array}$ & $\begin{array}{l}\text { contacted by mail and/ } \\
\text { or telephone to } \\
\text { participate } 2-4 \text { months } \\
\text { after giving birth }\end{array}$ & USA & $\begin{array}{l}2004- \\
2011\end{array}$ & 5 \\
\hline
\end{tabular}

Figure 1: Flow-chart of study selection. 


\begin{tabular}{|c|c|c|c|c|c|}
\hline Author & study design & exposure ascertainment & country & $\begin{array}{l}\text { study } \\
\text { year }\end{array}$ & $\begin{array}{l}\text { Quality } \\
\text { assessment }\end{array}$ \\
\hline $\begin{array}{l}\text { Mutsaerts } \\
2014[61]\end{array}$ & $\begin{array}{l}\text { population- } \\
\text { based } \\
\text { prospective } \\
\text { birth-cohort } \\
\text { study }\end{array}$ & $\begin{array}{l}\text { Shortly after delivery, } \\
\text { the midwife or } \\
\text { gynaecologist guiding } \\
\text { the pregnancy } \\
\text { completed a } \\
\text { questionnaire on } \\
\text { maternal alcohol use }\end{array}$ & Netherlands & $\begin{array}{l}2006- \\
2007\end{array}$ & 6 \\
\hline $\begin{array}{l}\text { Nugteren } \\
2012[62]\end{array}$ & $\begin{array}{l}\text { prospective } \\
\text { cohort }\end{array}$ & $\begin{array}{l}\text { alcohol consumption } \\
\text { was assessed by } \\
\text { questionnaires in each } \\
\text { trimester. }\end{array}$ & Netherlands & $\begin{array}{l}2002- \\
2006\end{array}$ & 7 \\
\hline $\begin{array}{l}\text { Walle } \\
2019[63]\end{array}$ & $\begin{array}{l}\text { cross- } \\
\text { sectional } \\
\text { study }\end{array}$ & $\begin{array}{l}\text { using interviewer } \\
\text { administered semi } \\
\text { structured questioner }\end{array}$ & Ethiopia & 2017 & 8 \\
\hline $\begin{array}{l}\text { Ye } \\
2014[64]\end{array}$ & $\begin{array}{l}\text { cross- } \\
\text { sectional } \\
\text { study }\end{array}$ & $\begin{array}{l}\text { All information was } \\
\text { collected on the basis of } \\
\text { standardized antenatal, } \\
\text { obstetric and neonatal } \\
\text { records. }\end{array}$ & China & 2011 & 7 \\
\hline
\end{tabular}

\section{Alcohol Consumption During Pregnancy And Pe}

We analyzed the association between maternal alcohol consumption with PE by using alcohol during pregnancy as a dichotomous variable, regardless of dosage, pattern, and time in the pregnancy. The total study population was 4,434,003 women with 170,481 PE cases in 29 studies. There was no significant association between alcohol consumption during pregnancy and incidence of PE $(\mathrm{OR}=0.93,95 \% \mathrm{Cl}$ : $0.73-1.20)$, with statistically significant heterogeneity among studies $\left(I^{2}=91 \%, P<0.00001\right)$ (Fig. 2$)$. Among the subgroup of prospective cohort studies $(n=7)$, the pooled results showed that alcohol consumption during pregnancy had a protective effect on $\mathrm{PE}(\mathrm{OR}=0.64,95 \% \mathrm{Cl}$ : $0.54-0.76)$, without statistically significant heterogeneity among these studies $\left(I^{2}=0 \%, P=0.56\right)$. The results from the subsets of retrospective cohort studies $(n=7)$ and case-control studies, in which alcohol exposure during pregnancy was determined through postpartum interviews or medical records, were consistent with the conclusion that alcohol consumption during pregnancy was not associated with PE, with an odds of 1.07 $(0.65-1.74)$ and $1.02(0.64-1.61)$, respectively. By visual inspection of the funnel plot, there was no significant publish bias (Fig. 3)

In the prospective subgroup, sensitivity analysis showed that the pooled results were stable. In the subgroup of retrospective cohort studies, when Salihu's study (2011)[20] was removed, the subtotal OR was changed to $1.47(1.36-1.58)$, and the heterogeneity was eliminated $\left(I^{2}=0 \%, p=0.45\right)$. In case-control 
studies subgroup, heterogeneity and pooled OR values did not change even when we removed studies in which the number of cases exposed to alcohol was less than 10 or low quality of the studies.

The literature identified on the dose-response and time-response relationship and quasi-experimental studies between maternal alcohol consumption and PE was limited and insufficient for meta-analysis, so we describe the relevant results as follows.

Regarding the time-response relationship between alcohol consumption, Leemaqz [19] et al reported that alcohol consumption at 15 weeks' gestation has a protective effect for PE with borderline significance 0.72 (0.53-0.99). At 20 weeks' gestation, there was not association with PE in a large prospective cohort study with 5588 nulliparous women (SCOPE).

When it comes to the dose-response relationship, McCarthy[21] reported that alcohol consumption of occasional to binge drinking before 15 weeks' gestation was not associated with the development of PE with an adjusted OR of $0.73(0.51-1.06)$ for occasional to low drinking and $0.66(0.39-1.14)$ for moderate to heavy alcohol consumption compared with abstinence in pregnancy. However, Salihu [20] used the Missouri maternally-linked cohort data files and the result showed that 1-2 drinks per week had protective effect for PE with an adjusted OR of $0.82(0.74-0.90)$. The protective effect disappeared for women consuming three to four drinks per week [OR 0.85 (95\% Cl: 0.64-1.14)] and more than five drinks per week [OR 1.05 (95\% Cl: 0.79-1.40)].

Mendelian randomization (MR), and family-based designs are approaches that can be used to improve causal inference. Only one study was family-based design. Lardoeyt et al[22] found a 16-fold increased risk of developing PE (OR 16) when first-degree family history (OR for sister with PE history is 1.61 alone) and alcohol consumption (OR is 4.44 alone) coexisted.

\section{Alcohol Consumption During Pregnancy And Hdp}

The 8 studies that had outcome variable of HDP. The total study population was 467,055 women with $41,708$ cases of HDP. The pooled estimates OR was 0.98 (95\% Cl: $0.75-1.29)$ with significant heterogeneity $\left(I^{2}=90 \% \mathrm{P}<0.00001\right)$ (Fig. 4). The funnel plot of the odds ratios for HDP shows an asymmetrical distribution, which indicates some publish bias (Fig. 5).

\section{Discussion}

To our knowledge, this is the first comprehensive systematic review on the effect of maternal alcohol consumption on PE and HDP. Overall, we find no significant association of alcohol consumption during pregnancy with PE or HDP. There was substantial heterogeneity among the included studies. Our review reveals that only a limited number of studies have been conducted on the association between alcohol consumption during pregnancy and the risk of PE or HDP. The quality of most included studies was low and many made no adjustment for potential confounders. Although we performed a meta-analysis to 
determine the overall risk, the presence of high heterogeneity suggests that these results must be interpreted cautiously.

Given the nature of alcohol as a risk factor for fetal complications, it is not feasible or ethical to designing and conducting a randomized controlled trial. Therefore we are limited to assessing this association using observational designs which have many problems including lack of adjustment, biases in reporting alcohol intake, sampling biases, etc [23]. These also have many problems which makes the interpretation challenging.

In prospective cohort study, information about alcohol consumption was mostly obtained through questionnaires before 20 weeks' gestation. On the other hand, in the retrospective cohort and case-control studies, alcohol exposure was assessed by questionnaires or retrospective medical records after delivery, which may introduce bias. Recall bias in postnatal reports of alcohol habits has been described [24], and such bias may contribute to heterogeneity in the reported associations in the retrospective cohort and case-control studies.

For the 7 prospective cohort studies, a potential protective effect of alcohol consumption during pregnancy on PE was observed. In a retrospective study by Salihu et al [20], the protective effect of alcohol on PE mainly came from the quite low dose of alcohol (1-2 drinks per weeks). At higher doses, the protective effect disappeared. In non-pregnant women, there was also a J-shaped relationship between alcohol consumption and hypertension, in which the protective effect was observed only in < $5 \mathrm{~g} /$ day [25] or $<10 \mathrm{~g} /$ day [26]. When women consumed 12-24 g/day, no association with hypertension was observed $(R R=0.94 ; 0.88-1.01)$ and when the dose was $\geq 36 \mathrm{~g} /$ day a harmful effect was observed (relative risk $=1.42 ; 1.22-1.66$ ) [27]. But we found no direct biological mechanism that supports the protective effect of alcohol on hypertension in literatures. Intervention studies for the effects of alcohol on blood pressure in non-pregnant women suggest that lower level alcohol has no effect on blood pressure [28]. The protective effect of lower alcohol was due to unmeasured confounders. One example for these confounders is socioeconomic status. Higher household income and highly educated women are more likely to drink alcohol during pregnancy [29]. Low socioeconomic status is a strong risk factor for preeclampsia[30]. The complexity of socioeconomic status makes it difficult to measure accurately.

Poor functioning of the placenta has been recognized as the root cause of PE. In vitro studies have shown that ethanol can induce apoptosis of placental trophoblast cells [31]. Animal experiments showed that exposure to ethanol during pregnancy reduced the invasion and differentiation of placental trophoblast cells and decreased the depth of placental implantation [32], and exposure to alcohol during pregnancy could increase blood pressure in pregnant rats [33]. Because observational studies are prone to bias and because in most included epidemiologic studies, no adjustment for potential confounding was conducted and no dose-response association analysis was performed.

Unmeasured confounders and limitations in the accurate assessment of drinking dose, frequency, mode, time and patterns may be the main reasons for the current inconsistencies in conclusions about the association between alcohol and PE or HDP. So in further studies, an assessment of dose-response could 
help to find out if the $\mathrm{J}$-shaped association observed in non-pregnant women with a protective effect at low dose while a harmful effect at high dose, also exists in pregnant women. Novel analytical approaches including mendelian randomization, family-based designs, and natural experiments can improve causal inference and overcome the limitation of confounder such as socioeconomic factors.

\section{Conclusions}

Our systematic review of currently available epidemiological studies on the association of alcohol consumption during pregnancy with PE or HDP found no apparent association. Conclusions obtained from different study designs are different. This makes it impossible to draw a firm conclusion. Unmeasured confounders and a lack of quantitative assessment of alcohol exposure may be the main reasons. Further studies should consider alternative designs such as mendelian randomization which can overcome some of the limitations of conventional prospective studies.

\section{Abbreviations}

PE

preeclampsia

HDP

hypertensive disorders of pregnancy

PROSPERO

International Prospective Register of Systematic Reviews

OR

odds ratio

$\mathrm{RR}$

risk ratio

NOS

Newcastle-Ottawa Scale

SCOPE

the SCreening for Pregnancy Endpoints study

\section{Declarations}

Ethics approval and consent to participate: Not applicable

Consent for publication: Not applicable

Availability of data and materials: All data generated or analyzed during this study are included in this article (and its supplementary files).

Competing interests: no competing interests are declared. 
Funding: This study was supported in part by grants from Canadian Institute of Health Research [FND148438]

\section{Authors' contributions:}

W.Y.G participated in the data collection, analysis, interpretation of data, and drafted the manuscript.

N.Z participated in the Study selection, data extraction, and analysis.

S.W.W coordinated the study and participated in the data analysis and critically revised the different versions of the manuscript.

D.J.C participated in the conception and design of the study, data analysis, and interpretation of data and commented on the manuscript.

All authors read and approved the final manuscript prior to submission.

Acknowledgements: Not applicable.

Authors' information (optional)》

\section{References}

1. Magee LA, Pels A, Helewa M, Rey E, von Dadelszen P. Canadian Hypertensive Disorders of Pregnancy Working G. Diagnosis, evaluation, and management of the hypertensive disorders of pregnancy: executive summary. J Obstet Gynaecol Can. 2014;36(5):416-41. doi:10.1016/s17012163(15)30588-0.

2. Say L, Chou D, Gemmill A, Tuncalp O, Moller AB, Daniels J, et al. Global causes of maternal death: a WHO systematic analysis. Lancet Glob Health. 2014;2(6):e323-33. doi:10.1016/S2214109X(14)70227-X.

3. Harmon QE, Huang L, Umbach DM, Klungsoyr K, Engel SM, Magnus P, et al. Risk of fetal death with preeclampsia. Obstet Gynecol. 2015;125(3):628-35. doi:10.1097/AOG.0000000000000696.

4. Stevens W, Shih T, Incerti D, Ton TGN, Lee HC, Peneva D, et al. Short-term costs of preeclampsia to the United States health care system. Am J Obstet Gynecol. 2017;217(3):237 - 48 e16. doi:10.1016/j.ajog.2017.04.032.

5. Craici I, Wagner S, Garovic VD. Preeclampsia and future cardiovascular risk: formal risk factor or failed stress test? Ther Adv Cardiovasc Dis. 2008;2(4):249-59. doi:10.1177/1753944708094227.

6. Wood AM, Kaptoge S, Butterworth AS, Willeit P, Warnakula S, Bolton T, et al. Risk thresholds for alcohol consumption: combined analysis of individual-participant data for 599912 current drinkers in 83 prospective studies. Lancet. 2018;391(10129):1513-23. doi:10.1016/S0140-6736(18)30134-X.

7. Roerecke M, Kaczorowski J, Tobe SW, Gmel G, Hasan OSM, Rehm J. The effect of a reduction in alcohol consumption on blood pressure: a systematic review and meta-analysis. Lancet Public 
Health. 2017;2(2):e108-e20. doi:10.1016/S2468-2667(17)30003-8.

8. Chen L, Smith GD, Harbord RM, Lewis SJ. Alcohol intake and blood pressure: a systematic review implementing a Mendelian randomization approach. PLoS Med. 2008;5(3):e52. doi:10.1371/journal.pmed.0050052.

9. Puddey IB, Mori TA, Barden AE, Beilin LJ. Alcohol and Hypertension-New Insights and Lingering Controversies. Curr Hypertens Rep. 2019;21(10):79. doi:10.1007/s11906-019-0984-1.

10. American College of 0 , Gynecologists. Committee on Health Care for Underserved W. Committee opinion no. 496: At-risk drinking and alcohol dependence: obstetric and gynecologic implications. Obstet Gynecol. 2011;118(2 Pt 1):383-8. doi:10.1097/AOG.0b013e31822c9906.

11. Carson G, Cox LV, Crane J, Croteau P, Graves L, Kluka S, et al. No. 245-Alcohol Use and Pregnancy Consensus Clinical Guidelines. J Obstet Gynaecol Can. 2017;39(9):e220-e54. doi:10.1016/j.jogc.2017.06.005.

12. Popova S, Lange S, Probst C, Parunashvili N, Rehm J. Prevalence of alcohol consumption during pregnancy and Fetal Alcohol Spectrum Disorders among the general and Aboriginal populations in Canada and the United States. Eur J Med Genet. 2017;60(1):32-48. doi:10.1016/j.ejmg.2016.09.010.

13. Wells GA. Shea B, Peterson DOC,J, Welch V, Losos M, Tugwell P,. The Newcastle-Ottawa Scale (NOS) for assessing the quality of nonrandomised studies in meta-analyses. http://wwwohrica/programs/clinical_epidemiology/oxfordasp. 2017.

14. Egger M, Davey Smith G, Schneider M, Minder C. Bias in meta-analysis detected by a simple, graphical test. BMJ. 1997;315(7109):629-34. doi:10.1136/bmj.315.7109.629.

15. Patsopoulos NA, Evangelou E, loannidis JP. Sensitivity of between-study heterogeneity in metaanalysis: proposed metrics and empirical evaluation. Int J Epidemiol. 2008;37(5):1148-57. doi:10.1093/ije/dyn065.

16. Bobic MV, Habek D, Habek JC. Perinatal epidemiological risk factors for preeclampsia. Acta Clinica Croatica. 2015;54(1):9-13.

17. Bandoli G, Palmsten K, Chambers CD, Jelliffe-Pawlowski LL, Baer RJ, Thompson CA. Revisiting the Table 2 fallacy: A motivating example examining preeclampsia and preterm birth. Paediatr Perinat Epidemiol. 2018,32(4):390-7. doi:10.1111/ppe.12474.

18. Wang Y, Zhao N, Qiu J, He X, Zhou M, Cui H, et al. Folic acid supplementation and dietary folate intake, and risk of preeclampsia. Eur J Clin Nutr. 2015;69(10):1145-50. doi:10.1038/ejcn.2014.295.

19. Leemaqz SY, Dekker GA, McCowan LM, Kenny LC, Myers JE, Simpson NA, et al. Maternal marijuana use has independent effects on risk for spontaneous preterm birth but not other common late pregnancy complications. Reprod Toxicol. 2016;62:77-86. doi:10.1016/j.reprotox.2016.04.021.

20. Salihu HM, Kornosky JL, Lynch O, Alio AP, August EM, Marty PJ. Impact of prenatal alcohol consumption on placenta-associated syndromes. Alcohol. 2011;45(1):73-9. doi:10.1016/j.alcohol.2010.05.010.

21. McCarthy FP, O'Keeffe LM, Khashan AS, North RA, Poston L, McCowan LM, et al. Association between maternal alcohol consumption in early pregnancy and pregnancy outcomes. Obstet 
Gynecol. 2013;122(4):830-7. doi:10.1097/AOG.0b013e3182a6b226.

22. Lardoeyt R, Vargas G, Lumpuy J, Garcia R, Torres Y. Contribution of genome-environment interaction to pre-eclampsia in a Havana Maternity Hospital. MEDICC Rev. 2013;15(3):22-9.

23. Hammer GP, du Prel JB, Blettner M. Avoiding bias in observational studies: part 8 in a series of articles on evaluation of scientific publications. Dtsch Arztebl Int. 2009;106(41):664-8. doi:10.3238/arztebl.2009.0664.

24. Feldman Y, Koren G, Mattice K, Shear H, Pellegrini E, MacLeod SM. Determinants of recall and recall bias in studying drug and chemical exposure in pregnancy. Teratology. 1989;40(1):37-45. doi:10.1002/tera.1420400106.

25. Taylor B, Irving HM, Baliunas D, Roerecke M, Patra J, Mohapatra S, et al. Alcohol and hypertension: gender differences in dose-response relationships determined through systematic review and metaanalysis. Addiction. 2009;104(12):1981-90. doi:10.1111/j.1360-0443.2009.02694.x.

26. Briasoulis A, Agarwal V, Messerli FH. Alcohol consumption and the risk of hypertension in men and women: a systematic review and meta-analysis. J Clin Hypertens (Greenwich). 2012;14(11):792-8. doi:10.1111/jch.12008.

27. Roerecke M, Tobe SW, Kaczorowski J, Bacon SL, Vafaei A, Hasan OSM, et al. Sex-Specific Associations Between Alcohol Consumption and Incidence of Hypertension: A Systematic Review and Meta-Analysis of Cohort Studies. J Am Heart Assoc. 2018;7(13). doi:10.1161/JAHA.117.008202.

28. Mori TA, Burke V, Beilin LJ, Puddey IB. Randomized Controlled Intervention of the Effects of Alcohol on Blood Pressure in Premenopausal Women. Hypertension. 2015;66(3):517-23. doi:10.1161/HYPERTENSIONAHA.115.05773.

29. Muggli E, O'Leary C, Donath S, Orsini F, Forster D, Anderson PJ, et al. "Did you ever drink more?" A detailed description of pregnant women's drinking patterns. BMC Public Health. 2016;16:683. doi:10.1186/s12889-016-3354-9.

30. Silva LM, Coolman M, Steegers EA, Jaddoe VW, Moll HA, Hofman A, et al. Low socioeconomic status is a risk factor for preeclampsia: the Generation R Study. J Hypertens. 2008;26(6):1200-8. doi:10.1097/HJH.0b013e3282fcc36e.

31. Clave S, Joya X, Salat-Batlle J, Garcia-Algar O, Vall O. Ethanol cytotoxic effect on trophoblast cells. Toxicol Lett. 2014;225(2):216-21. doi:10.1016/j.toxlet.2013.12.018.

32. Kalisch-Smith JI, Steane SE, Simmons DG, Pantaleon M, Anderson ST, Akison LK, et al. Periconceptional alcohol exposure causes female-specific perturbations to trophoblast differentiation and placental formation in the rat. Development. 2019;146(11):10. doi:10.1242/dev.172205.

33. Mankes RF, LeFevre R, Fieseher J, Santiago A, Benitz KF, Lyon R. Effects of ethanol on reproduction and arterial hypertension in spontaneously hypertensive and normotensive rats: a preliminary communication. Alcohol Clin Exp Res. 1985;9(3):284-90. doi:10.1111/j.1530-0277.1985.tb05751.x.

34. Bommarito PA, Kim SS, Meeker JD, Fry RC, Cantonwine DE, McElrath TF, et al. Urinary trace metals, maternal circulating angiogenic biomarkers, and preeclampsia: a single-contaminant and mixture- 
based approach. Environ Health. 2019;18(1). doi:10.1186/s12940-019-0503-5.

35. Chedraui P, Salazar-Pousada D, Villao A, Escobar GS, Ramirez C, Hidalgo L, et al. Polymorphisms of the methylenetetrahydrofolate reductase gene (C677T and A1298C) in nulliparous women complicated with preeclampsia. Gynecol Endocrinol. 2014;30(5):392-6. doi:10.3109/09513590.2014.895807.

36. Coolman M, Timmermans S, De Groot CJM, Russcher H, Lindemans J, Hofman A, et al. Angiogenic and fibrinolytic factors in blood during the first half of pregnancy and adverse pregnancy outcomes. Obstet Gynecol. 2012;119(6):1190-200. doi:10.1097/AOG.0b013e318256187f.

37. Cota LO, Guimaraes AN, Costa JE, Lorentz TC, Costa FO. Association between maternal periodontitis and an increased risk of preeclampsia. J Periodontol. 2006;77(12):2063-9. doi:10.1902/jop.2006.060061.

38. Endeshaw M, Ambaw F, Aragaw A, Ayalew A. Effect of Maternal Nutrition and Dietary Habits on Preeclampsia: A Case-Control Study. International Journal of Clinical Medicine. 2014;5(21):1405-16. doi:10.4236/ijcm.2014.521179.

39. Eskenazi B, Fenster L, Sidney S. A multivariate analysis of risk factors for preeclampsia. JAMA. 1991;266(2):237-41.

40. Fang R, Dawson A, Lohsoonthorn V, Williams MA. Risk Factors of Early and Late Onset Preeclampsia among Thai Women. Asian Biomed (Res Rev News). 2009;3(5):477-86.

41. Grum T, Seifu A, Abay M, Angesom T, Tsegay L. Determinants of pre-eclampsia/Eclampsia among women attending delivery Services in Selected Public Hospitals of Addis Ababa, Ethiopia: a case control study. BMC Pregnancy Childbirth. 2017;17(1):307. doi:10.1186/s12884-017-1507-1.

42. Jhee JH, Lee S, Park Y, Lee SE, Kim YA, Kang S-W, et al. Prediction model development of late-onset preeclampsia using machine learning-based methods. PLoS ONE. 2019;14(8):1-12. doi:10.1371/journal.pone.0221202.

43. Kharkova OA, Grjibovski AM, Krettek A, Nieboer E, Odland J. First-trimester smoking cessation in pregnancy did not increase the risk of preeclampsia/eclampsia: A Murmansk County Birth Registry study. PLOS ONE. 2017;12(8):1-12. doi:10.1371/journal.pone.0179354.

44. Kiondo P, Wamuyu-Maina G, Bimenya GS, Tumwesigye NM, Wandabwa J, Okong P. Risk factors for pre-eclampsia in Mulago Hospital, Kampala, Uganda. Trop Med Int Health. 2012;17(4):480-7. doi:10.1111/j.1365-3156.2011.02926.x.

45. Klonoff-Cohen HS, Edelstein SL. Alcohol consumption during pregnancy and preeclampsia. Journal of Women's Health. 1996;5(3):225-30. doi:10.1089/jwh.1996.5.225.

46. Kurki T, Hiilesmaa V, Raitasalo R, Mattila $H$, Ylikorkala O. Depression and anxiety in early pregnancy and risk for preeclampsia. Obstetrics Gynecology. 2000;95(4):487-90. doi:10.1016/s00297844(99)00602-x.

47. Lafaurie GI, Gomez LA, Montenegro DA, De Avila J, Tamayo MC, Lancheros MC, et al. Periodontal condition is associated with adverse perinatal outcomes and premature rupture of membranes in 
low-income pregnant women in Bogota, Colombia: a case-control study. J Matern Fetal Neonatal Med. 2020;33(1):16-23. doi:10.1080/14767058.2018.1484092.

48. Laine JE, Ray P, Bodnar W, Cable PH, Boggess K, Offenbacher S, et al. Placental Cadmium Levels Are Associated with Increased Preeclampsia Risk. PLoS ONE. 2015;10(10):1-9. doi:10.1371/journal.pone.0139341.

49. Meertens LJE, Scheepers HCJ, Van Kuijk SMJ, Aardenburg R, Van Dooren IMA, Langenveld J, et al. External Validation and Clinical Usefulness of First Trimester Prediction Models for the Risk of Preeclampsia: A Prospective Cohort Study. Fetal Diagn Ther. 2019;45(6):381-93. doi:10.1159/000490385.

50. Mekie M, Mekonnen W, Assegid M. Cohabitation duration, obstetric, behavioral and nutritional factors predict preeclampsia among nulliparous women in West Amhara Zones of Ethiopia: Age matched case control study. PLoS ONE. 2020;15(1):1-11. doi:10.1371/journal.pone.0228127.

51. Nobles CJ, Williams A, Ouidir M, Sherman S, Mendola P. Differential Effect of Ambient Air Pollution Exposure on Risk of Gestational Hypertension and Preeclampsia. Hypertension. 2019;74(2):384-90. doi:10.1161/HYPERTENSIONAHA.119.12731.

52. Rudra $\mathrm{CL}$, Williams MA. BMI as a modifying factor in the relations between age at menarche, menstrual cycle characteristics, and risk of preeclampsia. Gynecol Endocrinol. 2005;21(4):200-5. doi:10.1080/09513590500168431.

53. Sandström A, Snowden JM, Höijer J, Bottai M, Wikström A-K. Clinical risk assessment in early pregnancy for preeclampsia in nulliparous women: A population based cohort study. PLoS ONE. 2019;14(11):1-16. doi:10.1371/journal.pone.0225716.

54. Thompson ML, Ananth CV, Jaddoe VW, Miller RS, Williams MA. The association of maternal adult weight trajectory with preeclampsia and gestational diabetes mellitus. Paediatr Perinat Epidemiol. 2014;28(4):287-96. doi:10.1111/ppe.12128.

55. Xiong X, Wang FL, Davidge ST, Demianczuk NN, Mayes DC, Olson DM, et al. Maternal smoking and preeclampsia. J Reprod Med. 2000;45(9):727-32.

56. Xiong X, Zhang J, Fraser WD. Quitting smoking during early versus late pregnancy: the risk of preeclampsia and adverse birth outcomes. J Obstet Gynaecol Can. 2009;31(8):702-7. doi:10.1016/S1701-2163(16)34273-6.

57. Baugh N, Harris DE, Aboueissa AM, Sarton C, Lichter E. The Impact of Maternal Obesity and Excessive Gestational Weight Gain on Maternal and Infant Outcomes in Maine: Analysis of Pregnancy Risk Assessment Monitoring System Results from 2000 to 2010. J Pregnancy. 2016;2016:5871313. doi:10.1155/2016/5871313.

58. Perez-Chada D, Videla AJ, O'Flaherty ME, Majul C, Catalini AM, Caballer CA, et al. Snoring, witnessed sleep apnoeas and pregnancy-induced hypertension. Acta Obstet Gynecol Scand. 2007;86(7):78892. doi:10.1080/00016340701281919.

59. Iwama N, Metoki H, Nishigori H, Mizuno S, Takahashi F, Tanaka K, et al. Association between alcohol consumption during pregnancy and hypertensive disorders of pregnancy in Japan: the Japan 
Environment and Children's Study. Hypertens Res. 2019;42(1):85-94. doi:10.1038/s41440-018-01243.

60. Masho SW, Urban P, Cha S, Ramus R. Body Mass Index, Weight Gain, and Hypertensive Disorders in Pregnancy. Am J Hypertens. 2016;29(6):763-71. doi:10.1093/ajh/hpv184.

61. Mutsaerts MAQ, Groen H, Buiter-Van Der Meer A, Sijtsma A, Sauer PJJ, Land JA, et al. Effects of paternal and maternal lifestyle factors on pregnancy complications and perinatal outcome. A population-based birth-cohort study: The GECKO Drenthe cohort. Hum Reprod. 2014;29(4):824-34. doi:10.1093/humrep/deu006.

62. Nugteren JJ, Snijder CA, Hofman A, Jaddoe VWV, Steegers EAP, Burdorf A. Work-Related Maternal Risk Factors and the Risk of Pregnancy Induced Hypertension and Preeclampsia during Pregnancy. The Generation R Study. PLoS ONE. 2012;7(6):1-8. doi:10.1371/journal.pone.0039263.

63. Walle TA, Azagew AW. Hypertensive disorder of pregnancy prevalence and associated factors among pregnant women attending ante natal care at Gondar town health Institutions, North West Ethiopia 2017. Pregnancy Hypertens. 2019;16:79-84. doi:10.1016/j.preghy.2019.03.007.

64. Ye C, Ruan Y, Zou L, Li G, Li C, Chen Y, et al. The 2011 survey on hypertensive disorders of pregnancy (HDP) in China: prevalence, risk factors, complications, pregnancy and perinatal outcomes. PLoS ONE. 2014;9(6):e100180. doi:10.1371/journal.pone.0100180.

\section{Figures}

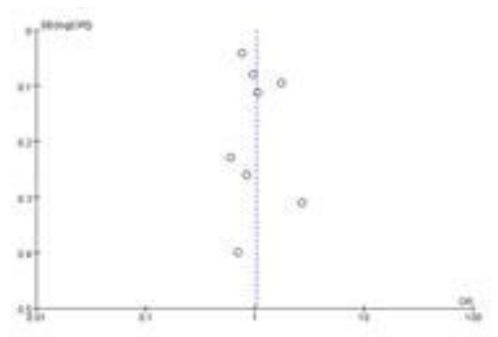

\section{Figure 1}

Funnel plot corresponding to the random-effects meta-analysis of the association between alcohol consumption during pregnancy and HDP

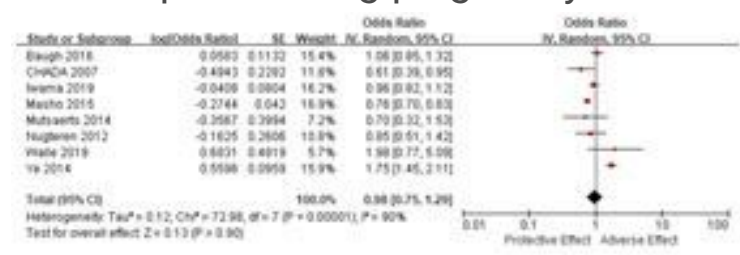

\section{Figure 2}


Forest plots (random effect model) of meta-analysis on the association between alcohol consumption during pregnancy and incidence of HDP

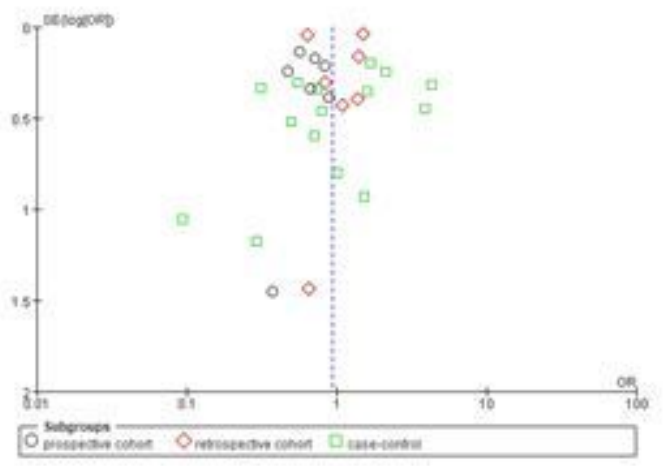

\section{Figure 3}

Funnel plot corresponding to the random-effects meta-analysis of the association between alcohol consumption during pregnancy and PE risk.

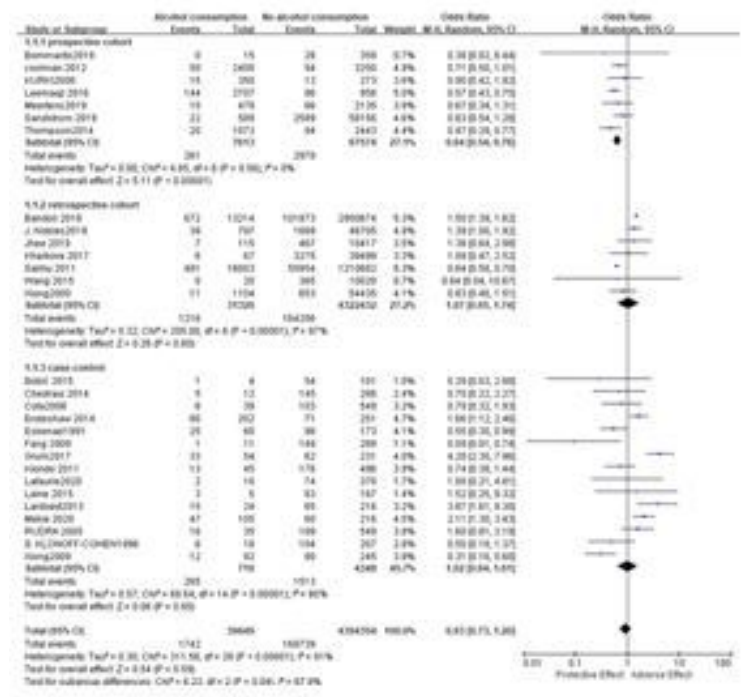

\section{Figure 4}

Forest plots (random effect model) of meta-analysis on the association between alcohol consumption during pregnancy and incidence of PE. 


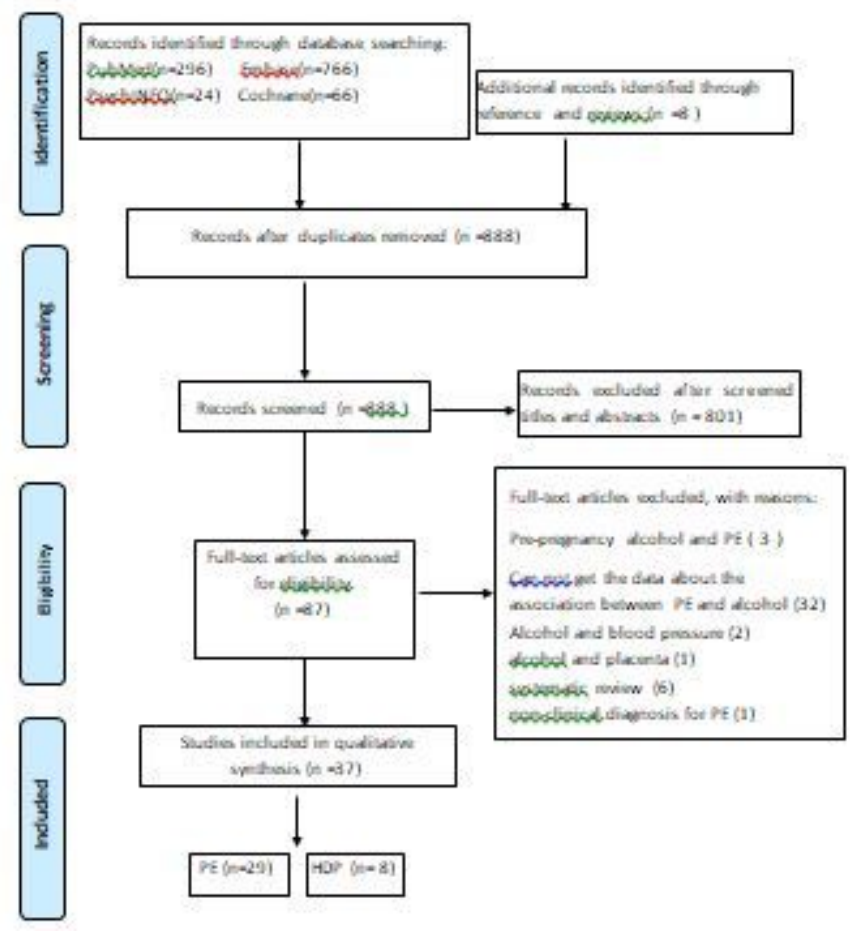

Figure 5

Flow-chart of study selection.

\section{Supplementary Files}

This is a list of supplementary files associated with this preprint. Click to download.

- Additionalfile1.docx 